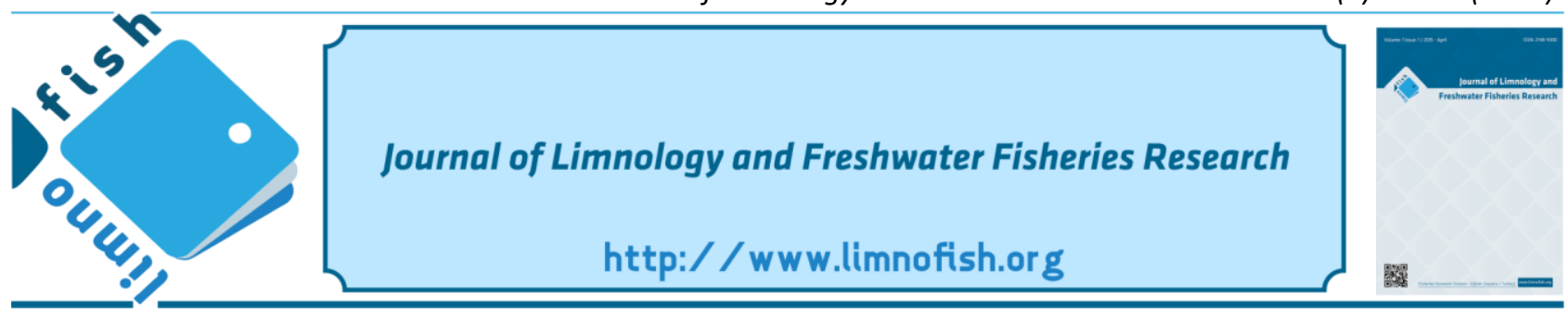

\title{
Pseudorasbora parva (Temminck \& Schlegel, 1846): A New Threat to Fish Biodiversity in Ordu Province (Middle Black Sea Region)
}

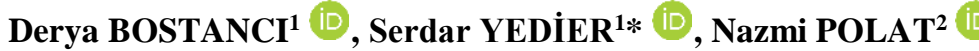 \\ ${ }^{1}$ Ordu University, Faculty of Arts and Sciences, 52200 Ordu-Turkey \\ ${ }^{2}$ Ondokuz Mayıs University, Faculty of Arts and Sciences, 55139 Samsun-Turkey
}

\section{A B STRACT}

The invasive fish species pose a significant threat to both local fish species and aquatic habitats. During the field surveys, an invasive fish species Pseudorasbora parva was found for the first time in Ulugöl (Ordu). In the field studies, 41 $P$. parva individuals from different size groups were captured. Total length (TL), fork length (FL), standard length (SL) and weight (W) of this invasive species which continuously increase distribution in Turkish inland waters were recorded. The average TL, FL, SL and W values of the $P$. parva were $7.24 \pm 1.2 \mathrm{~cm}$ $(3.8-9.4 \mathrm{~cm}), 6.52 \pm 1.1 \mathrm{~cm}(3.4-8.4 \mathrm{~cm}), 5.73 \pm 0.9 \mathrm{~cm}(3.0-7.1 \mathrm{~cm})$ and $3.24 \pm 1.4 \mathrm{~g}(0.4415-6.8632 \mathrm{~g})$, respectively. P. parva species was reported as the first record in Ordu (Middle Black Sea Region). The increase in the number of $P$. parva individuals in Ulugöl is a great threat to Ordu fish biodiversity.

Keywords: Freshwater fishes, invasive fish species, Topmouth gudgeon, Ordu

\section{ARTICLE INFO}

$\begin{array}{ll}\text { SHORT COMMUNICATION } \\ \text { Received } & \text { : } 6.05 .2019 \\ \text { Revised } & : 28.08 .2019 \\ \text { Accepted } & : 26.09 .2019 \\ \text { Published } & : 25.04 .2020\end{array}$

DOI:10.17216/LimnoFish.560633

\section{* CORRESPONDING AUTHOR}

serdar7er@gmail.com

Phone : +90 4522339149

Pseudorasbora parva (Temminck \& Schlegel, 1846): Ordu'da (Orta Karadeniz Bölgesi) Balık Biyoçeşitliliğine Yeni Bir Tehdit

Öz: İstilacı balık türleri hem yerel balık türleri hem de akuatik habitatlar için önemli bir tehdit oluşturmaktadır. Yapılan arazi çalışmaları sırasında Ordu ilinde ilk kez Ulugöl'de istilacı bir balık türü olan Pseudorasbora parva'ya rastlanmıştır. Arazi çalışmalarında farklı boy gruplarına ait 41 adet $P$. parva bireyleri yakalanmıştır. Türkiye iç sularında yayılış alanını devamlı olarak artıran bu istilacı türün total boy (TB), çatal boy (ÇB), standart boy (SB) ve ağırlıkları (W) kayıt altına alınmıştır. $P$. parva bireylerinin ortalama TB, ÇB, SB and W değerleri sirasiyla 7,24 $\pm 1,2 \mathrm{~cm}(3,8-9,4 \mathrm{~cm}), 6,52 \pm 1.1 \mathrm{~cm}(3,4-8,4 \mathrm{~cm}), 5,73 \pm 0,9 \mathrm{~cm}$

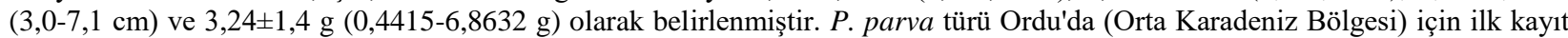
olarak rapor edilmiştir. Ulugöl'de $P$. parva bireylerinin sayılarının artması Ordu balık biyoçeşitliliği için çok büyük bir tehdit oluşturmaktadır.

Anahtar kelimeler: Tatlı su balıkları, istilacı balık türü, Çakıl balığı, Ordu.

How to Cite

Bostanci D, Yedier S, Polat N. 2020. Pseudorasbora parva (Temminck \& Schlegel, 1846): A New Threat to Fish Biodiversity in Ordu Province (Middle Black Sea Region). LimnoFish. 6(1): 52-58. doi: 10.17216/LimnoFish.560633

\section{Introduction}

Turkey is one of the very rich countries in terms of freshwater ichthyofauna due to the geological position and topographic structure (Tarkan et al. 2015; Çiçek et al. 2018). 409 fish species were reported in the inland water of Turkey. Among these fish species, 194 are endemic and 28 are non-native species for Turkish inland waters (Çiçek et al. 2015; Çiçek et al. 2018).

Maintaining biodiversity in natural and artificial habitats is vital for a sustainable environment and future. The freshwater fish fauna is under threat due to many different reasons such as numbers of water canals and dams in the system, domestic waste, introduction of invasive species, uncontrolled pesticide use, and habitat degradation (Özuluğ et al. 2013; Tarkan et al. 2015). These activities increase the negative effect of feeding, breeding and sustaining the species of fish which are found naturally in the freshwater source, or cause a decrease in the population or the continuity of the generation (Ekmekçi et al. 2013).

Invasive species have many negative impacts on ecosystem, local and national economies as well as 
their negative effects on food and habitat competition, predation, hybridization, disease and parasites transport on native species (Kennard et al. 2005; Ekmekçi and Kırankaya 2006). Easy adaptation to environmental conditions, early sexual maturation, successful reproductive strategies and wide nutritional tolerance play an important role in the success of invasive species spreading into habitats (Carman et al. 2006).

Topmouth gudgeon, Pseudorasbora parva (Temminck \& Schlegel, 1846) which is a member of the Cyprinidae family, are freshwater fish of Asian origin and they can find in many different freshwater habitats (Banarescu 1999). It is widely spread in lakes and ponds which are very rich in terms of water plants (Kottelat and Freyhof 2007). P. parva mouth is upward, small and has no barbels around it. Their caudal fin is homocerc. The most prominent feature is the black band that starts right behind the head and extends to the caudal. During the breeding period, small tubercles are found in the head region of the $P$. parva as in many carp. In addition, during this period, pigmentation on the outer part of the scales becomes darker in males and therefore male and female individuals are more easily discriminated (Froese and Pauly 2018). The species is usually $2 \mathrm{~cm}$ to $7.5 \mathrm{~cm}$ in length it can reach up to $12.5 \mathrm{~cm}$ in length. According to the IUCN criteria, $P$. parva is considered Least Concern (LC) (Huckstorf 2012).

$P$. parva which is an invasive fish species was reported in the Thrace region in 1982 for the first time in Turkey (Erk'akan 1984). This fish species, which has many invasive features, has spread rapidly to many Turkish freshwater basins (Çetinkaya 2006; Ekmekçi et al. 2013; Özuluğ et al. 2019). However, there is no record of $P$. parva in the freshwater habitats in the Ordu. Unfortunately, a new record has been added to the distribution areas of P. parva which is known as one of the most important invasive freshwater fish species of Turkey.

\section{Materials and Methods}

Ulugöl is a small lake located in Ulugöl Nature Park in Gölköy district of Ordu province. Ulugöl has an area of 39 decares with 5-20 m depth at an altitude of $1200 \mathrm{~m}$. This lake is formed as a result of the accumulation of water in the space formed by the landslide mass, the formation form is very different from the landslide lakes in the Black Sea Region (Taş et al. 2010). Carp (Cyprinus carpio) and endemic Abant trout (Salmo abanticus) which were released in 2007 during the stocking activities trout live in the Ulugöl (Anonymous 2012a; Anonymous 2012b).
The fish samples were captured using the electrosocker at along the Ulugöl lakeshore from the (Ordu) at $40^{\circ} 37^{\prime} 48^{\prime} ' \mathrm{~N}$ and $37^{\circ} 32^{\prime} 46^{\prime \prime}$ E coordinates (Figure 1). The captured fish samples were brought dead to the Hydrobiology laboratory at Ordu University with the fish transport containers.

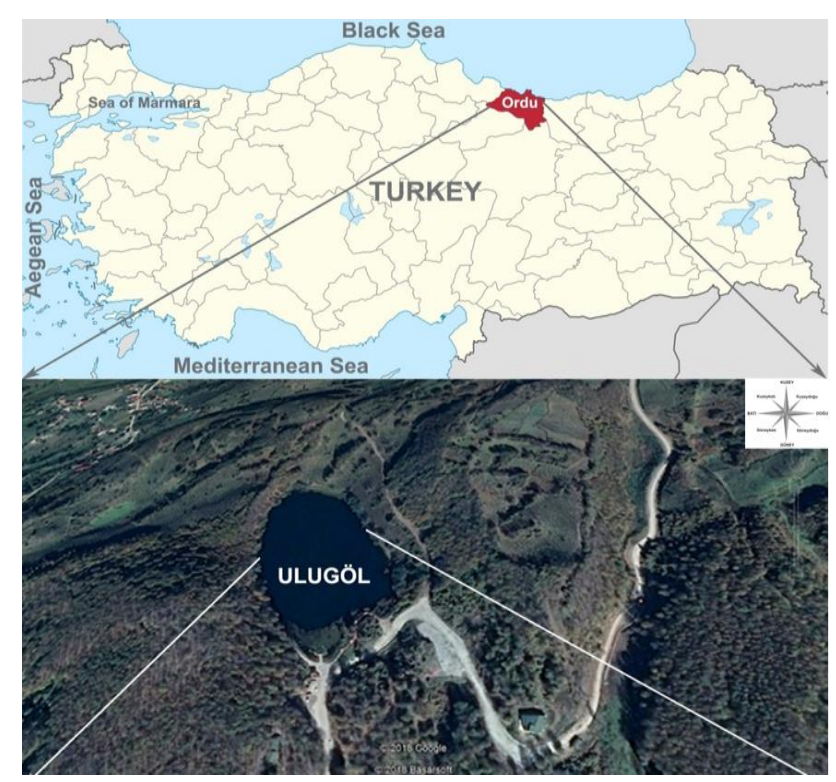

Figure 1. Sampling area (adapted from GoogleEarth and Wikipedia).

All fish samples were identified using different studies (Kuru 1980; Kottelat and Freyhof 2007) and identification keys. Then, the sex determinations of these samples were made both microscopically and macroscopically according to their size. Some meristic and metric characters such as fish weight (nearest $\pm 0.1 \mathrm{~g}$ ), total length, fork length and standard length (nearest $\pm 0.1 \mathrm{~cm}$ ) were measured for each $P$. parva samples. The weight-frequency and lengthfrequency distributions were determined.

\section{Results}

In this study, $41 P$. parva were caught from different parts of the Ulugöl (Ordu) during the fieldwork (Figure 2). Maximum and minimum values of total length, fork length, standard length and weight of the samples with mean and standard deviation $3.8 \mathrm{~cm}$ and $9.4 \mathrm{~cm}(7.24 \pm 1.2), 3.4 \mathrm{~cm}$ and $8.4 \mathrm{~cm}(6.52 \pm 1.1), 3.0 \mathrm{~cm}$ and $7.1 \mathrm{~cm}(5.73 \pm 0.9)$ and 0.4415-6.8632 g (3.24 \pm 1.4$)$, respectively. The male and female $P$. parva samples from Ulugöl are shown in Figure 2.

It was determined that $P$. parva fish samples from Ulugöl were $60.97 \%$ female and $39.03 \%$ male. As a result of t-test, there was no statistical difference between weight and length values of male and female samples $(P>0.05)$. 


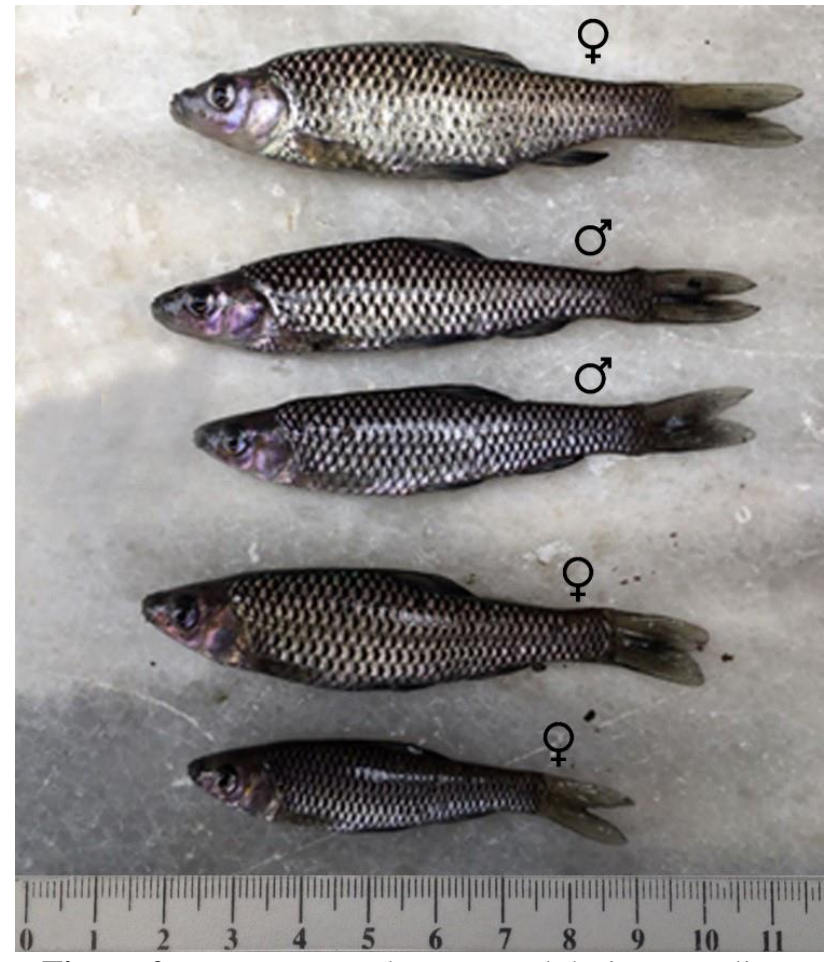

Figure 2. $P$. parva samples captured during sampling.

$P$. parva fish fin rays formulas are determined as
Anal: III 6, Dorsal: II-III 7-8, Pektoral: I 8-12, and Ventral: I 7-8. The line lateral scales of the samples are between 36-40 and the pharyngeal teeth are 5-5. In the current study, we also examined the length and weight frequency of this invasive fish species. The weight-frequency and length-frequency distributions were presented in Figure 3.

\section{Discussion}

The introduction of invasive fish species into new aquatic environments in different pathways such as natural introduction, human introduction and involuntary introduction has dramatically increased the damage to these habitats. The existence of $P$. parva invasive species was recorded for the first time in Ulugöl (Ordu). The determination of the presence of $P$. parva is a major problem for both Ulugöl natural life and Ordu fish biodiversity. Male and female individuals belonging to different size groups have been captured (Figure 2). It proves that this species adapts to the Ulugöl and has successfully bred in the Ulugöl. Although 41 samples were captured in the sampling period, they were visually observed in an excessive amount of this species.
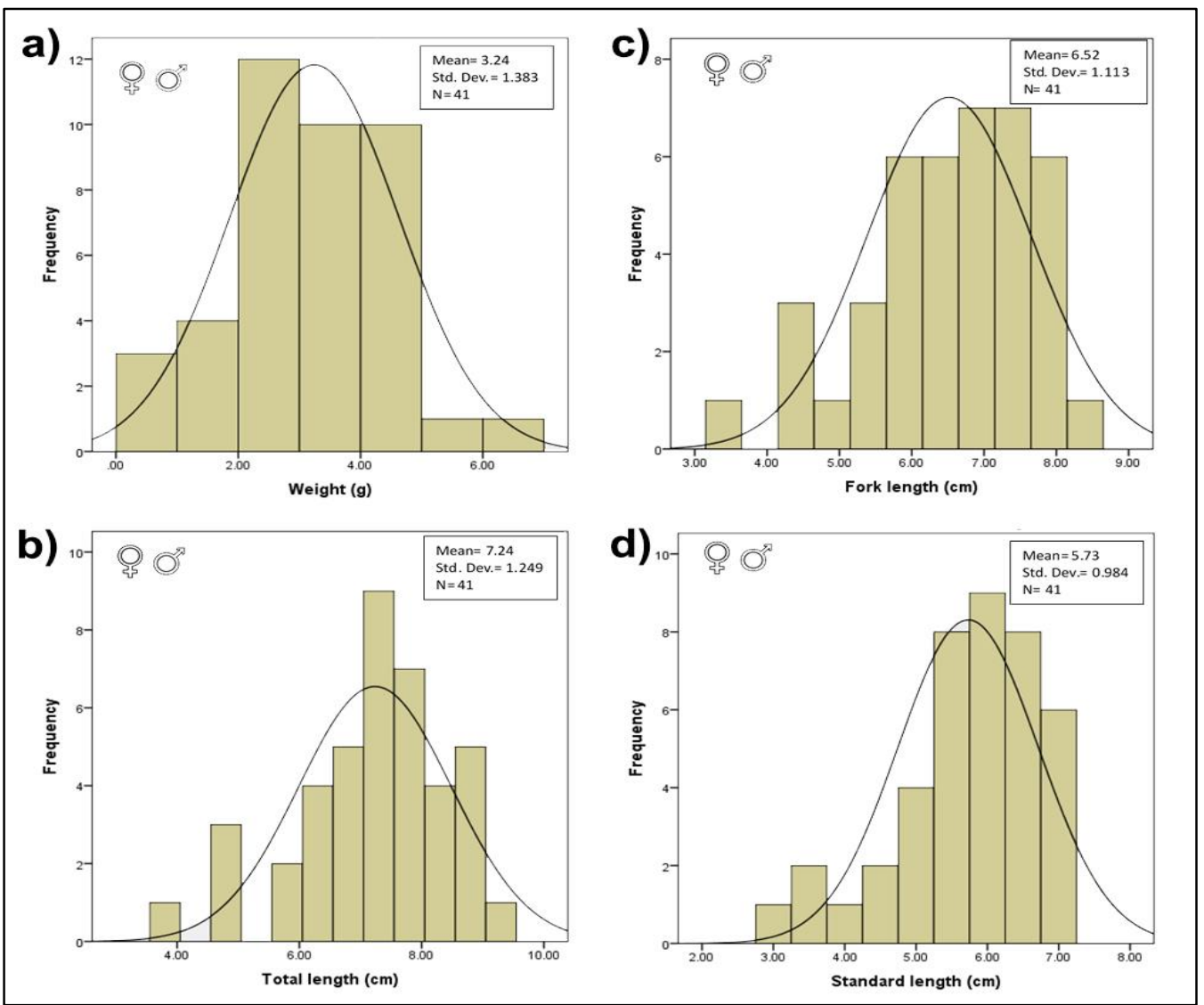

Figure. 3. The weight-frequency and length-frequency distributions of $P$. parva from Ulugöl (Ordu).

$P$. parva can easily settle when transported to a reservoir in any way and it can be destructive for the other fish species due to its parasites (Andreou and Gozlan 2016). P. parva have also negative impacts on the native fish fauna via competition foods, spawning areas, and other sources (Ekmekçi et al. 2013). C. carpio and S. abanticus inhabited in the Ulugöl (Anonymous 2012a; Anonymous 2012b). 
Therefore, it is important to investigate the relationship of $P$. parva with $C$. carpio and $S$. abanticus in Ulugöl fish fauna and its effects on these economic fish species. In many studies, control activities were focused on the destruction of $P$. parva from natural waters in some European countries, especially in the UK (Britton and
Brazier 2006; Britton et al. 2010).

This is the new record for the distribution of P. parva in Ordu inland waters. Since 1984, P. parva has expanded the distribution areas within 35 years and has established successful populations in Turkish inland waters. In the studies it is clear that P. parva quickly spread to Turkey inland waters (Table 1).

Table 1. Distribution areas of $P$. parva in Turkey.

\begin{tabular}{|c|c|c|c|}
\hline $\begin{array}{r}\text { Locations } \\
\end{array}$ & References & $\begin{array}{r}\text { Locations } \\
\end{array}$ & References \\
\hline Meriç River (Edirne) & Erk'akan 1984 & Yenice Dam (Eskişehir) & Yeğen et al. 2015 \\
\hline Aksu River (Antalya) & Wildekamp et al. 1997 & Bahçecik Pond (Eskişehir) & Yeğen et al. 2015 \\
\hline $\begin{array}{l}\text { Karacaören I Reservoirs (Isparta- } \\
\text { Burdur) }\end{array}$ & Becer \& İkiz 2001 & Erenköy Pond (Eskişehir) & Yeğen et al. 2015 \\
\hline $\begin{array}{l}\text { Topçam Dam Lake (Büyük } \\
\text { Menderes) }\end{array}$ & Şaşı \& Balık 2003 & Günyüzü II Pond (Eskişehir) & Yeğen et al. 2015 \\
\hline Dipsiz-Çine Stream (Aydın) & Barlas \& Dirican 2004 & Koçaş II Pond (Eskişehir) & Yeğen et al. 2015 \\
\hline $\begin{array}{l}\text { Karacaören II Reservoirs (Isparta- } \\
\text { Burdur) }\end{array}$ & Küçük \& İkiz 2004 & Mercan Pond (Eskişehir) & Yeğen et al. 2015 \\
\hline Sarıyar Dam Lake (Ankara) & $\begin{array}{l}\text { Ekmekçi \& Kırankaya } \\
2006\end{array}$ & Akın Creek (Eskişehir) & Yeğen et al. 2015 \\
\hline Yortanlı Creek (Bakırçay Havzası) & $\begin{array}{l}\text { Ekmekçi \& Kırankaya } \\
2006\end{array}$ & Porsuk River (Eskişehir) & Yeğen et al. 2015 \\
\hline Filyos- Devrek Creek (Zonguldak) & İnnal \& Erk'akan 2006 & Çavdarhisar Dam (Kütahya) & Yeğen et al. 2015 \\
\hline Gölcük Lake (Isparta) & Yeğen et al. 2006 & Enne Dam (Kütahya) & Yeğen et al. 2015 \\
\hline Sarıçay (Muğla) & Y1lmaz et al. 2006 & Kayaboğazı Dam (Kütahya) & Yeğen et al. 2015 \\
\hline Bekdiğin Pond (Samsun) & Uğurlu \& Polat 2007 & Söğüt Dam (Kütahya) & Yeğen et al. 2015 \\
\hline Ağaçköy Stream (Batı Karadeniz) & İlhan \& Balık 2008 & Doğluşah Pond (Kütahya) & Yeğen et al. 2015 \\
\hline Felek Stream (Bat1 Karadeniz) & İlhan \& Balık 2008 & Dumlupınar Pond (Kütahya) & Yeğen et al. 2015 \\
\hline Hirfanlı Dame Lake (Kırşehir) & Kurankaya et al. 2009 & Pazarlar Pond (Kütahya) & Yeğen et al. 2015 \\
\hline Akgöl (Sinop) & Yardım \& Erdem 2010 & Sekiören Pond (Kütahya) & Yeğen et al. 2015 \\
\hline Gönen Stream (Balıkesir) & İlhan et al. 2012 & Altıntaş Pond (Uşak) & Yeğen et al. 2015 \\
\hline Beyşehir Lake (Konya) & Meke et al. 2012 & Göğem Pond (Uşak) & Yeğen et al. 2015 \\
\hline Gelingüllü Dam Lake (Yozgat) & Özdilek et al. 2013 & Gökçeada (Çanakkale) & Bakaç et al. 2017 \\
\hline Ulubat Lake (Bursa) & Çınar et al. 2013 & Demirköprü Reservor (Manisa) & Karakuş et al. 2017 \\
\hline Marmara Lake (Manisa) & İlhan \& Sar1 2013 & Afşar Reservoir (Manisa) & Karakuş et al. 2017 \\
\hline Ula Reservoir (Muğla) & Keskin et al. 2013 & Görde Stream (Manisa) & Karakuş et al. 2017 \\
\hline Bayraktar Reservoir (İzmit) & Keskin et al. 2013 & Gediz River (Manisa) & Karakuş et al. 2017 \\
\hline Kirazoğlu Reservoir (İzmit & Keskin et al. 2013 & Demirci Stream (Manisa) & Karakuş et al. 2017 \\
\hline Davuldere Reservoir (İzmit) & Keskin et al. 2013 & $\begin{array}{l}\text { Kemerdamları Drainage } \\
\text { (Manisa) }\end{array}$ & Karakuş et al. 2017 \\
\hline Meyil Lake (Konya) & Özuluğ et al. 2013 & Gödet Creek (Karaman) & Küçük et al. 2018 \\
\hline Evri Stream (Kahramanmaraş) & Özuluğ et al. 2013 & Gödet Reservoir (Karaman) & Küçük et al. 2018 \\
\hline Kemer Reservoir (Aydın) & Şaş1 \& Berber 2013 & Deliçay Reservoir (Karaman) & Küçük et al. 2018 \\
\hline Topçam Reservoir (Aydın) & Şaşı \& Berber 2013 & İbrala Reservoir (Karaman) & Küçük et al. 2018 \\
\hline Lake Eğirdir (Isparta) & Yerli et al. 2013 & Ayranc1 Reservoir (Karaman) & Küçük et al. 2018 \\
\hline Moğan Lake (Ankara) & Özeren \& Arslan 2014 & $\begin{array}{l}\text { Abdürrahimköyü Stream } \\
\text { (Marmara Basin) }\end{array}$ & Özuluğ et al. 2019 \\
\hline Dodurga Dam (Bilecik) & Yeğen et al. 2015 & $\begin{array}{l}\text { Anaçay Stream (Meriç-Ergene } \\
\text { Basin) }\end{array}$ & Özuluğ et al. 2019 \\
\hline Kızıldamlar Dam (Bilecik) & Yeğen et al. 2015 & $\begin{array}{l}\text { Kocaçay Stream (Meriç-Ergene } \\
\text { Basin) }\end{array}$ & Özuluğ et al. 2019 \\
\hline Küçükelmalı Pond (Bilecik) & Yeğen et al. 2015 & $\begin{array}{l}\text { Kovakçeşme Stream (Meriç- } \\
\text { Ergene Basin) }\end{array}$ & Özuluğ et al. 2019 \\
\hline Onaç Dam (Burdur) & Yeğen et al. 2015 & $\begin{array}{l}\text { Muzalı Stream (Meriç-Ergene } \\
\text { Basin) }\end{array}$ & Özuluğ et al. 2019 \\
\hline Çatören Dam (Eskişehir) & Yeğen et al. 2015 & $\begin{array}{l}\text { Sazlıdere Stream (Meriç-Ergene } \\
\text { Basin) }\end{array}$ & Özuluğ et al. 2019 \\
\hline Gökçekaya Dam (Eskişehir) & Yeğen et al. 2015 & $\begin{array}{l}\text { Seymendere Stream (Meriç- } \\
\text { Ergene Basin) }\end{array}$ & Özuluğ et al. 2019 \\
\hline Kaymaz Dam (Eskişehir) & Yeğen et al. 2015 & $\begin{array}{l}\text { Uzunçay Stream (Meriç-Ergene } \\
\text { Basin) }\end{array}$ & Özuluğ et al. 2019 \\
\hline Kunduzlar Dam (Eskişehir) & Yeğen et al. 2015 & Ulugöl (Ordu) & This Study \\
\hline
\end{tabular}


$P$. parva was accidentally introduced into the Ulugöl in the course of stocking with $C$. carpio. In addition, many amateur fishing activities are carried out in Ulugöl, and local and traditional fishing competitions with competitors from different regions are organized. It is thought that $P$. parva may be spread by hunting or fishing activities used in different watersheds. In order to prevent the spread of this fish species in the inland waters of Ordu, flyers and leaflets can be a useful way of promoting public awareness about the invasive fish. In addition, people and fishermen in that area should be informed about the fishing gear used in fishing in Ulugöl not to be used in other ecosystems.

Invasive freshwater fish species continue to increase steadily in many freshwater habitats (İnnal 2012). There are many reasons for the high success of $P$. parva species in the Turkish inland waters such as reproduction activity rate during the breeding season, sexual maturation at an early age, relatively large eggs, male guarding eggs and short life cycle of the species (Ekmekçi and Kırankaya 2006). Ekmekçi and Kirankaya (2006) reported that $P$. parva can lay eggs in branches, leaves, plastic waste from the habitats. Therefore, when the consider the problem of the Ulugöl with aquatic plants, it is observed that this contributes to increase in the number of $P$. parva compared to other fish species in the habitat.

The reduction of biodiversity or the disappearance of certain species makes biological resources unusable and useless. On the other hand, when it comes to genetics, biodiversity becomes even more important. Biotechnological developments that will benefit human beings and ecosystems in the future depend on the wealth of gene pools of biological resources (Polat et al. 2011). Considering studies related to Turkish ichthyofauna, information for these destructive effects on the aquatic ecosystems of invasive fish species which increases the distribution area in Turkish inland waters is quite limited (Özuluğ et al. 2013). In order to avoid irreparable losses in fish biodiversity of Turkey, the distribution areas of these invasive species should be identified. Necessary management actions should be given to the fisheries studies about identifying possible mechanisms of invasive fish action on native fish species in the habitats such as disease, hybridization, food and habitat competition. Because of that the necessary steps against the occurrence of the invasive species and the species should be monitored in the habitats.

\section{References}

Andreou D, Gozlan RE. 2016. Associated disease risk from the introduced generalist pathogen
Sphaerothecum destruens: management and policy implications. Parasitology. 143(9): 1204-1210. doi: 10.1017/S003118201600072X

Anonymous 2012a. T.C. Tarım ve Orman Bakanlığı 11. Bölge Müdürlüğü, Ulugöl tabiat park1. [cited 2019 Aug 27]. Available from http://ordu.ormansu.gov.tr/Ordu/AnaSayfa/Tabiat_Pa rklari/dkmp_tabiatparki.aspx?sflan335\&sflang=tr

Anonymous 2012b. T.C. Tarım ve Orman Bakanlığı 11. Bölge Müdürlüğü, Gölköy Ulugöl'e 15 bin adet Abant Alası cinsi alabalık salındı. [cited 2019 Aug 27]. Available from http://ordu.ormansu.gov.tr/ordu/anasayfa/resimlihabe r/121102/G\%C3\%B6lk\%C3\%B6y_Ulug\%C3\%B61\% E2\%80\%99e_15_bin_adet_\%E2\%80\%98Abant_Ala s\%C4\%B1\%E2\%80\%99_cinsi_alabal\%C4\%B1k_sal $\% \mathrm{C} 4 \% \mathrm{~B} 1 \mathrm{nd} \% \mathrm{C} 4 \% \mathrm{~B} 1$.aspx?sflang=tr

Bakaç İ, Yalçın Özdilek Ş, Ekmekçi FG. 2017. First record for invasive Topmouth gudgeon Pseudorasbora parva (Temminck and Schlegel, 1846) from Gökçeada (Çanakkale). EgeJFAS. 34(4): 459-462.

doi: 10.12714/egejfas.2017.34.4.14

Banarescu PM. 1999. Gobio (Cuvier, 1816). In: Banarescu PM, editor. The freshwater fishes of Europe. Vol. 5/I: Cyprinidae 2/I. Wiebelsheim: Aula-Verlag. p. 33-36.

Barlas M, Dirican S. 2004. The fish fauna of the DipsizÇine (Muğla-Aydın) stream. GU J Sci. 17(3): 35-48.

Becer ZA, İkiz R. 2001. Karacaören I Baraj Gölü'ndeki eğrez Vimba vimba tenella (Nordmann, 1840) populasyonunun bazı üreme özellikleri. Turk $\mathrm{J}$ Vet Anim Sci. 25(1): 111-117.

Britton JR, Brazier M. 2006. Eradicating the invasive topmouth gudgeon, Pseudorasbora parva, from a recreational fishery in Northern England. Fisheries Manag Ecol. 13(5): 329-335. doi: 10.1111/j.1365-2400.2006.00510.x

Britton JR, Davies GD, Brazier M. 2010. Towards the successful control of Pseudorasbora parva in the UK. Biol Invasions. 12(1):125-131. doi: 10.1007/s10530-009-9436-1

Carman SM, Janssen J, Jude DJ, Berg MB. 2006. Diel interactions between prey behaviour and feeding in an invasive fish, the round goby, in a North American river. Freshwater Biol. 51(4): 742-755. doi: 10.1111/j.1365-2427.2006.01527.x

Çetinkaya O. 2006. Türkiye sularına aşılanan veya stoklanan egzotik ve yerli balık türleri, bunların yetiştiricilik, balıkçılık, doğal populasyonlar ve sucul ekosistemler üzerindeki etkileri veri tabanı için bir ön çalışma. Paper presented at: Balıklandırma ve Rezervuar Yönetimi Sempozyumu; Antalya, Turkey. [in Turkish]

Çınar Ş, Küçükkara R, Balık İ, Çubuk H, Ceylan M, Erol KG, Yeğen V, Bulut C. 2013. Uluabat (Apolyont) Gölü'ndeki balık faunasının tespiti, tür kompozisyonu ve ticari avcılığın türlere göre dağılımı. J Fish Sci. 7(4): 309-316. doi: $10.3153 /$ jfscom. 2013034

Çiçek E, Birecikligil SS, Fricke R. 2015. Freshwater fishes of Turkey: a revised and updated annotated checklist. Biharean Biol. 9(2): 141-157. 
Çiçek E, Fricke R, Sungur S, Eagderi, E. 2018. Endemic freshwater fishes of Turkey. FishTaxa. 3(4): 1-39.

Ekmekci FG, Kırankaya Ş. 2006. Distribution of an invasive fish species, Pseudorasbora parva (Temminck \& Schlegel, 1846) in Turkey. Turk J Zool. 30(3): 329-334.

Ekmekçi FG, Kırankaya, ŞG, Gençoğlu L, Yoğurtçuoğlu B. 2013. Türkiye içsularındaki istilacı balıkların güncel durumu ve istilanın etkilerinin değerlendirilmesi. İstanbul Uni $\mathrm{Su}$ Ürün Derg. 28(1):105-140.

Erk'akan F. 1984. Trakya Bölgesi'nden Türkiye için yeni kayıt olan bir balık türü Pseudorasbora parva (Cyprinidae). Doğa Bilim Derg. A2: 350-351.

Froese R, Pauly D. 2018. Fishbase, Species list: Pseudorasbora parva; [cited 2018 Sep 23]. Available from https://www.fishbase.se/summary/4691

Huckstorf V. 2012. Pseudorasbora parva. The IUCN Red List of Threatened Species 2012: e.T166136A1114203. [cited 2019 Aug 25]. Available from https://www.iucnredlist.org/species/166136/1114203

İlhan A, Balık S. 2008. Batı Karadeniz Bölgesi iç sularının balık faunas1. EgeJFAS. 25(1): 75-82.

İlhan A, Sarı HM, Ustaoğlu MR. 2012. Gönen Çayı (Balıkesir) balık faunası. Paper presented at: V. Ulusal Limnoloji Sempozyumu; Isparta, Turkey. [in Turkish]

İlhan A, Sarı HM. 2013. Marmara Gölü balık faunası ve balıkçılık faaliyetleri. EgeJFAS. 30(4): 187-191.

İnnal D, Erk'akan F. 2006. Effects of exotic and translocated fish species in the inland waters of Turkey. Rev Fish Biol Fisher. 16(1): 39-50. doi: 10.1007/s11160-006-9005-y

İnnal D. 2012. Alien fish species in reservoir systems in Turkey: a review. Manag Biol Invasion. 3(2): 115119. doi: 10.3391/mbi.2012.3.2.06

Karakuş U, Top-Karakuş N, Tarkan AS. 2017. Distribution and new records of non-native Pseudorasbora parva in Manisa Province, Turkey. Paper presented at: II. Workshop on Invasive Species: Global meeting on invasion ecology; Bodrum, Turkey.

Kennard MJ, Arthington AH, Pusey BJ, Harch BD. 2005. Are alien fish a reliable indicator of river health? Freshwater Biol. 50(1): 174-193. doi: 10.1111/j.1365-2427.2004.01293.x

Keskin E, Ağdamar S, Tarkan AS. 2013. DNA barcoding common non-native freshwater fish species in Turkey: Low genetic diversity but high population structuring. Mitochondr DNA. 24(3): 276-287. doi: 10.3109/19401736.2012.748041

Kırankaya GS, Ekmekçi GF, Yalçın Özdilek S, Yoğurtçuoğlu B, Gencoğlu L. 2009. Preliminary data on an invasive fish, Pseudorasbora parva, from Hirfanlı Dam Lake in Turkey. Paper presented at: 13th European Congress of Ichthyology; Klaipeda, Lithuania.

Kottelat M, Freyhof J. 2007. Handbook of European freshwater fishes. Kottelat, Cornol, Switzerland and Freyhof, Berlin, Germany.
Küçük F, İkiz R. 2004. Antalya Körfezi’ne dökülen akarsuların balık faunası. EgeJFAS. 21(3): 287-294.

Küçük F, Güçlü SS, Gülle İ. 2018. New habitat records for invasive Atherina boyeri, Carassius gibelio and Pseudorasbora parva (Teleostei) from Turkey. Paper presented at: International Symposium Ecology; Kastamonu, Turkey.

Kuru M. 1980. Key to the Inland Water Fishes of Turkey, Part I, II, III. Hacettepe Bull Nat Sci Eng. 9: 103-133.

Meke T, Küçükkara R, Çınar Ş, Çavdar N, Babar B, Yener O. 2012. Beyşehir Gölü balık faunası için yeni bir kayıt: istilacı bir tür: Pseudorasbora parva (Temminck \& Schlegel, 1846). Paper presented at: V. Limnology Symposium; Isparta, Turkey. [in Turkish]

Özdilek (Yalçın) Ş, Kırankaya ŞG, Ekmekçi FG. 2013. Feeding ecology of the Topmouth gudgeon Pseudorasbora parva (Temminck and Schlegel, 1846) in the Gelingüllü reservoir, Turkey. Turk J Fish Aquat Sci. 13(1): 87-94. doi: 10.4194/1303-2712-v13_1_1

Özeren SC, Arslan P. 2014. Mogan Gölü'nde yaşayan Pseudorasbora parva'nın Ligula intestinalis ile enfekte olmuş ve olmamış bireylerinde kondisyon faktörü karşılaştırılması. Paper presented at: 22. National Biology Congress; Eskişehir, Turkey. [in Turkish]

Özuluğ M, Gaygusuz Ö, Gürsoy Gaygusuz Ç, Saç G. 2019. New distribution areas of four invasive freshwater fish species from Turkish Thrace. Turk J Fish \& Aquat Sci. 19(10): 837-845. doi: 10.4194/1303-2712-v19_10_03

Özuluğ M, Saç G, Gaygusuz Ö. 2013. İstilacı özellikteki Gambusia holbrooki, Carassius gibelio ve Pseudorasbora parva (Teleostei) türleri için Türkiye'den yeni yayılım alanları. J Fish Aquat Sci. 28: 1-22.

Polat N, Zengin M, Gümüş A. 2011. İstilacı balık türleri ve hayat stratejileri. Karadeniz Fen Bil Dergisi / The Black Sea Journal of Sciences. 1(4):63-86.

Şaşı H, Balık S. 2003. The distribution of three exotic fishes in Anatolia. Turk J Zool. 27(4): 319-322.

Şaşı H, Berber S. 2013. The indigenous and invasive fishes in two main reservoirs in the southwestern Anatolia (Aydin). UNED Research Journal. 5(1): 97-101. doi: 10.22458/urj.v5i1.237

Tarkan AS, Marr SM, Ekmekçi FG. 2015. Non-native and translocated freshwater fish species in Turkey. FiSHMED Fishes in Mediterranean Environments 2015. 003: 28p. doi: 10.29094/FiSHMED.2015.003

Taş B, Candan AY, Can Ö, Topkara S. 2010. Ulugöl (Ordu)'ün bazı fiziko-kimyasal özellikleri. Journal of FisheriesSciences, 4(3): 254-263.

Uğurlu S, Polat, N. 2007. Samsun ili tatlı su kaynaklarında yaşayan egzotik balık türleri. Journal of FisheriesSciences.com. 1(3): 139-151. doi: 10.3153/jfscom.2007017

Wildekamp RH, Van Neer W, Küçük F, Ünlüsayın M. 1997. First record of the eastern Asiatic gobionid fish Pseudorasbora parva from the asiatic part of Turkey. J Fish Biol. 51(4): 858-868. 
doi: 10.1111/j.1095-8649.1997.tb02006.x

Yardım Ö, Erdem Y. 2010. Sinop ilinde bulunan bazı lentik sulardaki istilacı balık türlerinin durumu. Paper presented at: 4th National Limnology Symposium; Bolu, Turkey. [in Turkish]

Yeğen V, Balık S, Bostan H, Uysal R, Bilçen E. 2006.

Göller Bölgesi'ndeki bazı göl ve baraj göllerinin balık faunalarının son durumu. Paper presented at: I.Ulusal Balıklandirma ve Rezervuar Yönetimi Sempozyumu; Antalya, Turkey. [in Turkish]

Yeğen V, Uysal R, Yağcı A, Cesur M, Çetinkaya S, Bilgin F, Bostan H, Yağc1 M. 2015. New records for distribution of invasive Topmouth $\mathrm{g}$ udgeon (Pseudorasbora parva Temmnick \& Schlegel, 1846) in Anatolia. LimnoFish. 1(1): 57-61. doi: 10.17216/LimnoFish-5000092903

Yerli SV, Alp A, Yeğen V, Uysal R, Yağcı MA, Balık I. 2013. Evaluation of the ecological and economical results of the introduced alien fish species in Lake Eğirdir, Turkey. Turk J Fish \& Aquat Sci. 13(5): 795809.

doi: 10.4194/1303-2712-v13_5_03

Yılmaz F, Barlas M, Yorulmaz B, Özdemir N. 2006. A Taxonomical study on the inland water fishes of Muğla. EgeJFAS. 23(1-2): 27-30. 